
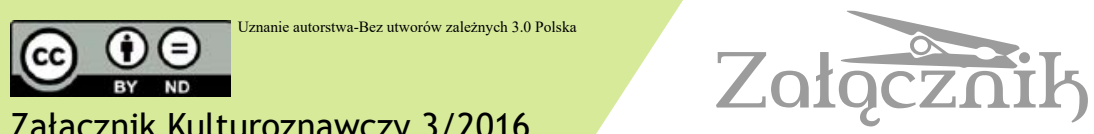

Załącznik Kulturoznawczy 3/2016

TEMAT NUMERU: KICZ NASZ WSPÓLCZESNY

\title{
REFLEKSJA O KICZU ARCHITEKTONICZNYM. ILUZJA CZY NAMIASTKA SZCZĘŚCIA?
}

\author{
BARBARA STEC
}

Akademia Sztuk Pięknych w Krakowie

Academy of Fine Arts in Cracow (Poland)

bara.stec@gmail.com

„Architektura jest pełna kiczu!” - stwierdził Kurt W. Forster, znawca i krytyk architektury, w wywiadzie udzielonym mi w 2005 roku$^{1}$. Wtedy, jedenaście lat temu, temat kiczu w publicystyce architektonicznej pojawiał się przede wszystkim z związku z ówczesnymi kontrowersyjnymi realizacjami - rozmaitymi parkami rozrywki i galeriami handlowymi. Wcześniej, w latach 80 . i 90., temat ten był w Polsce rozważany w kontekście postmodernizmu w architekturze. Obecnie pojęcie kiczu pojawia się przede wszystkim w związku z refleksją nad autentycznością architektury. Można więc stwierdzić, że kicz jest również pojęciem krytyki architektonicznej i że co jakiś czas powraca ono w dyskusjach - w kolejnych swoich interpretacjach - wraz ze zjawiskami, które miałoby charakteryzować. Jednak początkowo kicz nie dotyczył architektury.

Jak wiadomo, termin 'kicz' został wprowadzony około 1870 roku przez środowisko monachijskich malarzy dla określenia obrazów ocenianych przez nich jako tandetne i bezwartościowe. Za obrazami kryli się ich autorzy i nabywcy, czyli ludzie i ich postawy, ale dopiero z czasem pojęcie kiczu przeszło do innych dziedzin twórczości artystycznej, następnie zaś do estetyki, filozofii czy psychologii. Swoista kariera tego pojęcia pokazuje, że zjawisko to, odkąd zostało nazwane, zaczęło nurtować krytyków sztuki, filozofów, psychologów i samych twórców, prowokując do kolejnych jego interpretacji. Wydaje się jednak, że do dziś utrzymuje się w mocy pierwotne znaczenie terminu 'kicz', a rozmaite jego filozoficzne wyjaśnienia

1 B. Stec, Powtórne spojrzenie, cz. 1, „Architektura \& Biznes” 2005, nr 5 (154), s. 75. 
i artystyczne interpretacje nie tyle zmieniają jego sens, co zakres objętych nim zjawisk, podając odmienne przyczyny ich powstawania, mechanizmy funkcjonowania oraz skutki, jakie powodują dla życia człowieka, społeczeństwa i sztuki, a w przypadku architektury - także dla przestrzeni architektonicznej, urbanistycznej i krajobrazowej.

Rodzi się zatem pytanie, czy zjawisko kiczu architektonicznego trzeba wyodrębniać jako osobny byt, czy raczej wystarczy odnaleźć je w szerszej dyskusji na temat kiczu w rozmaitych przejawach twórczości i życia człowieka? Zapewne da się zaadaptować ogólną charakterystykę kiczu także do architektury, łatwo jednak zauważyć, że kicz jej przynależny musi wiązać się z fizyczną, czasową i przestrzenną skalą dzieł architektonicznych, odniesioną do fizycznych rozmiarów człowieka i rozpiętości czasu, w którym on żyje, a także związaną bezpośrednio z użytkową funkcją samej architektury. Skala dzieła architektonicznego jest odmienna od skali obrazu, rzeźby, utworu literackiego lub muzycznego. Pojęcie kiczu w momencie swego pojawienia się dotyczyło przedmiotów o rozmiarach znacznie mniejszych niż przeciętne dzieło architektoniczne, i nadal jeszcze bywa odnoszone przede wszystkim do drobiazgu, bibelotu, landschaftu, czyli czegoś, co można z łatwością schować do szafy i usunąć sprzed oczu. Fizyczna skala architektury na to nie pozwala, a co więcej - pociąga ona za sobą równie dużą skalę psychologicznych, kulturowych i socjologicznych konsekwencji związanych z użytkownikiem architektury i jej oddziaływaniem na otoczenie.

\section{ILUZJA}

W refleksji nad kiczem w architekturze chciałabym odnieść się do innej wypowiedzi K.W. Forstera zawartej w cytowanym już wcześniej wywiadzie, w której określił on kicz mianem iluzji, a tym samym poruszył dyskutowaną aktualnie kwestię autentyczności. Forster stwierdził:

Termin ten [kicz - przyp. B.S.], według mnie, określa iluzję, że wszystko jest wspaniale i ślicznie. Jest to udawanie, że świat jest jak w bajce, że żona kocha męża i odwrotnie, że dzieci są grzeczne i cudowne i że sielanka istnieje na co dzień, podczas gdy wcale tak nie jest. Takie myślenie niczym życzenie albo złudzenie bardzo łatwo przełożyć na formę architektury, pełną marzeń i naiwności. Są to budynki tworzone przez ludzi albo dla ludzi, którzy nie 
mają odwagi spojrzeć na świat realnie i zobaczyć dojrzale jego złożoności dostępnej naszemu poznaniu ${ }^{2}$.

Widać więc, że Forster odwołuje się do kiczu jako postawy człowieka wobec rzeczywistości, w czym można zauważyć nawiązanie do koncepcji Theodora Adorno. Kicz jest zatem nierozerwalnie związany z ludzkim wartościowaniem rzeczywistości i nie istnieje sam w sobie, poza ludzką świadomością i oceną, na przykład w przyrodzie. Nie są kiczem żadne zjawiska i elementy przyrody, wliczając w to zachody słońca i jelenie na rykowisku, natomiast mogą się one nim stać jedynie jako temat ludzkich wytworów albo przedmiot przeżyć, czyli w związku z konkretną postawą człowieka wobec tychże zjawisk.

Wyprowadzając kicz w architekturze od zjawiska psychologicznego, a nie estetycznego (co mogłaby sugerować geneza pojęcia), Forster uwypukla przyczynę jego powstawania. Zwraca tym samym uwagę, że wartościujące określenie dzieła architektury jako kiczu wymaga rozeznania w szerszym kontekście jego funkcjonowania: postawy i motywacji zleceniodawcy, sytuacji życiowej użytkownika, lokalizacji, przeznaczenia, funkcjonalności architektury itd. Za przyczynę kiczu w architekturze uznaje on iluzję tkwiącą w naiwnym, życzeniowym myśleniu człowieka, która to iluzja zostaje następnie wcielona $\mathrm{w}$ formę budynku - pozbawioną odniesień do realnego życia jego użytkowników i realnych warunków jego lokalizacji. Mogą to być na przykład zapożyczenia $\mathrm{z}$ architektury ulubionego stylu historycznego zleceniodawcy albo z innego miejsca, najczęściej atrakcyjniejszego od przestrzeni lokalnej. W rezultacie takiej iluzji powstaje budynek określany jako nieautentyczny, nieprzynależny do swojego rzeczywistego miejsca i czasu. Czy jednak taki budynek zawsze musi być kiczem?

\section{ARCHITEKTONICZNA SKALA ILUZJI}

Refleksja nad wartościującym określaniem dzieła architektonicznego jako kiczu w oparciu o kryterium iluzji prowadzi do wspomnianego już zagadnienia skali architektonicznej, a także użytkowości architektury, która jest jej podstawową funkcją. W architekturze, ze względu na wspomniane wyżej jej właściwości i cele, iluzja nie może zastąpić rzeczywistego spełnienia

2 Ibidem. 
potrzeb życiowych ${ }^{3}$ użytkownika i z tego powodu jest krótkotrwała (jako przyczyna konkretnego ukształtowania jej formy albo złudzenie funkcjonalności na terenie „zabawy”). Utrwalenie iluzji w czasie i przestrzeni fizycznej, o ile w ogóle jest możliwe, prowadzi do sytuacji, w której dzieło architektoniczne stanowi atrapę rzeczywistości i nie jest w stanie zaspokajać potrzeb użytkowników.

Kicz występujący poza polem architektury łatwo utożsamić z iluzją głównie ze względu na krótkotrwałość jego oddziaływania na człowieka. Jak wspomniałam, początkowo dotyczył on przedmiotów o rozmiarach obrazka, wchodzących z człowiekiem w ograniczony przestrzennie i krótkotrwały kontakt. Do dziś przedmioty takie, nawet przy stosunkowo dużych rozmiarach (w doświadczeniu kiczu skala czasowa wydaje się ważniejsza od skali przestrzennej), towarzyszą człowiekowi jedynie przez tę chwilę, w której są percypowane. Nie dotyczą one jego realnych potrzeb i stanowią wyłącznie dodatek do realiów egzystencji, pozostając w obszarze marzeń i życzeń. Jeśli rozszerzyć pojęcie kiczu na zachowania człowieka, to także można zauważyć, że uczucie egzaltacji (zaliczone do kiczu przez Hermanna Brocha) albo „wzruszenie nad własnym wzruszeniem” (uznane za kicz przez Ludwiga Geisza ${ }^{4}$ ) trwają wyłącznie przez chwilę. W skali, którą można by nazwać tradycyjną skalą czasową kiczu, jego rolą jest właśnie tworzenie iluzji - udawanie, okłamywanie siebie i innych, pomieszanie rzeczywistego z nierzeczywistym. Nie ma wówczas większego znaczenia, czy kicz-iluzja tworzony oraz odbierany jest jako żart, czy na serio, ponieważ nie wkracza on na grunt rzeczywistych potrzeb życiowych człowieka i nie obiecuje, że je spełni. Jest kiczem, i jego rolą jest właśnie iluzja.

Na podobnej zasadzie istnieje kicz-iluzja architektury, który można nazwać (nieświadomym lub programowym) kiczem w architekturze,

3 Włodzimierz Szewczuk definiuje potrzebę (zarówno w ogólnym sensie, jak i odnosząc ją do każdego osobnika) jako „stan powstający w wyniku zakłócenia optimum życiowego organizmu, inicjujący jego aktywność ukierunkowaną na osiągnięcie czegoś, co przywraca owo optimum w mniejszym lub większym stopniu”. Hasło: 'Potrzeba', [w:] Encyklopedia psychologii, red. Wł. Szewczuk, Warszawa 1998, s. 434.

4 Zob. K. Baumann, O kiczu, campie $i$ architekturze ujarzmionej pragmatyzmem, „Architektura \& Biznes” 2005, nr 5(154), s. 32-41. 
widoczny w budynkach, w których człowiek przebywa tylko od czasu do czasu i na tyle krótko, by nie wkraczać na grunt swoich elementarnych potrzeb życiowych. Przestrzenna skala architektoniczna sprawia, że użytkownik takiego budynku jest zagarniany przez iluzyjne formy i zwykle zgadza się na nie, tak jakby akceptował dekoracje teatralne w spektaklu, w którym sam ma zostać aktorem i widzem jednocześnie. Nawet w roli aktora dostrzega on jednak, że iluzja jest oddzielona od rzeczywistości i wyodrębniona $z$ niej - jako teren iluzji właśnie. Może ona przez chwilę stymulować jego zachowanie i odczucia, prowadzić do przeżycia „fałszywego katharsis", o którym pisał Adorno, albo po prostu do zapomnienia o rzeczywistości, szarej i pełnej problemów. Taki kicz-iluzja może przybrać skalę budynku (Colosseo w Parku Europa, arch. Svenja Reich, Chemnitz 2004), placu (Plac d'Italia, arch. Charles Moore, Nowy Orlean 1974), a nawet miasta (Las Vegas). Jeśli chodzi o oddziaływanie na człowieka, tak rozumiany kicz w architekturze nie różni się od kiczu w malarstwie albo rzeźbie, gdyż funkcjonuje w im właściwej skali czasowej (sporadycznie i krótkotrwale). Różni się natomiast w kwestii tego, jak oddziałuje na krajobraz - pozostaje utrwaloną atrapą, czyli kiczem o skali architektonicznej.

Myślę, że Forster poruszył w swojej wypowiedzi właśnie taki, albo również taki, aspekt iluzji, która prowadzi do powstawania nie tyle kiczu w a rchitekturze, co kiczu architektonicznego - do oszukiwania samego siebie w długim czasie życia człowieka, w skali domu lub krajobrazu, które człowiek zamieszkuje. Co dzieje się z iluzją, którą próbuje się zastąpić rzeczywistą funkcjonalność domu w jej architektonicznym sensie? Forster zauważa, że częstokroć forma domu odzwierciedlać ma rozmaite marzenia zleceniodawców: wyrażać pragnienie życia w innym (w stosunku do rzeczywistego) czasie lub miejscu albo też posiadania wysokiej pozycji społecznej - zamożności, prestiżu, przynależności do określonej klasy itp. Taki rodzaj iluzji jest z natury niejako architektoniczny - może zrodzić się jedynie w skali architektury, wymaga bowiem miejsca, przestrzeni, czasu budowania i zamieszkiwania, dużych nakładów finansowych, trwania w krajobrazie. W ten sposób powstają „budynki tworzone przez ludzi albo dla ludzi, którzy nie mają odwagi spojrzeć na świat realnie i zobaczyć dojrzale jego złożoności dostępnej naszemu poznaniu”. Wobec skali ich iluzji fotografia uśmiechających się do siebie, a w rzeczywistości skłóconych członków 
rodziny albo odbitka weneckiego widoczku wisząca na ścianie wydają się kiczem zupełnie niewinnym.

Polska rzeczywistość lat 70. i 80. stała się wyjątkowo podatnym gruntem dla marzeń o estetyce innej niż ta, jaka wówczas obowiązywała - odległej zarówno historycznie, jak i geograficznie. W tamtym czasie jednak tylko nieliczni obywatele mieli możliwość zrealizowania domu swoich marzeń: „nowego starego dworku szlacheckiego”, chaty podhalańskiej pod Warszawą, willi „australijskiej” albo „hiszpańskiej” w Małopolsce. W latach transformacji znacznie więcej Polaków zaczęło podróżować i utożsamiać swoje marzenia o lepszym życiu $\mathrm{z}$ formami domów typowych dla obcego krajobrazu, na przykład śródziemnomorskiego, skandynawskiego, amerykańskiego. Czy jednak zapożyczenia formalne w architekturze koniecznie muszą być kiczem?

Wydaje się, że nie. W przypadku budynków, które z założenia nie stanowią „terenu iluzji”, trudno „przedłużyć” jej trwanie i przenieść ją w rzeczywisty czas i przestrzeń architektury, w ramach których człowiek spełnia swe potrzeby życiowe. Trudno także „przełożyć” iluzję na fizyczne wymiary budowli, ponieważ konkretne funkcje wymagają konkretnych, rzeczywistych rozmiarów przestrzennych (iluzjonistycznie namalowany pokój nie doda realnej powierzchni mieszkalnej, podobnie jak iluzja tarasu nie pozwoli człowiekowi zaczerpnąć świeżego powietrza). Ostatecznie funkcje życiowe człowieka są spełniane zawsze w rzeczywistości. W tym sensie architektura, która umożliwia realizację tych funkcji, zawsze jest rzeczywista, bez względu na swoją formę. Rzeczywiste pozostają również prawa fizyki. Iluzja może więc dotyczyć przede wszystkim dekoracji: okładziny ściany, ornamentów, które nie pełnią ani funkcji konstrukcyjnej, ani strukturalnej, a także dyspozycji przestrzennej budowli i atmosfery architektury.

Widać więc, że iluzja, która jako marzenie i życzenie zleceniodawcy częstokroć jest przyczyną powstania zapożyczeń formalnych, rzadko kiedy po z o sta je iluzją, czyli atrapą rzeczywistej, funkcjonalnej formy domu. A jeśli zapożyczone formy spełniają funkcje życiowe użytkownika i stymulują jego życie w rzeczywistości, to na czym miałaby zasadzać się ich iluzyjność? Zatem nawet w sytuacji, kiedy przyczyną powstania tych form była iluzja, ich użyteczność w spełnianiu realnych potrzeb człowieka sprawia, że iluzja, „wcielona” w rzeczywistość, znika. Jednakże aby nastąpiło takie „wcielenie”, iluzja musi spełniać realną potrzebę człowieka, na przykład potrzebę piękna, 
której nie zastąpi pusty efekt piękna ani informacja o pięknie. Forma realnie organizująca wokół siebie i spełniająca potrzeby życiowe człowieka nie jest już iluzją, zatem nie może być też kiczem w zarysowanym powyżej sensie.

Kiedy jednak iluzja pozostaje w architekturze bezużyteczną atrapą rzeczywistości, wykluczoną z funkcji zaspokajania potrzeb użytkownika, wówczas tworzy kicz architektoniczny, pogłębiający w człowieku poczucie braku możliwości spełnienia zarówno marzeń, jak i realnych potrzeb. Ostatecznie kicz działa jako informacja o niespełnieniu, nie zaś jako spełnienie marzenia, nawet częściowe, jak w przypadku tak zwanej „namiastki szczęścia”.

Można zatem zaproponować tezę, iż w architekturze, w związku z jej użytkowym charakterem, skalą czasową i przestrzenną, iluzja może, ale nie musi prowadzić do powstania kiczu architektonicznego. Iluzja, która nie spełnia żadnej funkcji architektonicznej związanej z zaspokajaniem życiowych potrzeb użytkownika, prowadzi do powstania bezużytecznej atrapy rzeczywistości, czyli właśnie kiczu architektonicznego. Kicz taki można rozpoznać po tym, że wzbudza w człowieku smutek i irytację, ukazując mu skalę jego niespełnienia (działa jak informacja o braku). Natomiast iluzja nie prowadzi do powstania kiczu architektonicznego, kiedy istnieje wyłącznie jako przyczyna powstania architektury, ale znika w zrealizowanej (choć zapożyczonej) formie, która jest architektonicznie użyteczna (na przykład jako rzeczywista dekoracja teatralna lub przedmiot o wartości estetycznej). W związku z tym także ornament nie musi być kiczem, jeśli przekształca iluzję w „namiastkę szczęścia”.

\section{NAMIASTKA SZCZĘŚCIA NIE MUSI BYĆ KICZEM}

Namiastka szczęśliwego życia, zbudowana na podstawie marzenia lub życzenia zleceniodawcy, nie musi być tandetna i wykonana $z$ lichych materiałów. Wiele jest przykładów wcielania marzeń i życzeń w formę architektoniczną, które ocenia się jako wyraz wysokich aspiracji ludzi albo pozytywnie wartościowanego snobizmu. Bogaci mieszczanie od dawna aspirowali do warunków życia typowych dla arystokracji. Życzenie wynikające z podziwu dla określonej formy architektonicznej czy obcych kultur może być źródłem inspiracji i owocować eklektyzmem, który nie zawsze jest oceniany negatywnie w kryteriach estetycznych. Na przykład dawna rezydencja królewska - Pawilon Jerzego IV w Brighton - jest takim właśnie marzeniem, nawiązującym do stylu indosaraceńskiego (stanowi połączenie neogotyku 
z architekturą państwa Wielkich Mongołów), ale zrealizowanym z wielkim kunsztem artystycznym. I choć wygląda obco w kontekście lokalnej architektury, kojarzy się z dziewiętnastowiecznymi Indiami, gdzie pracowało wielu brytyjskich architektów. W aranżacji wnętrz Pawilonu wymieszano elementy indyjskie, chińskie i islamskie. Pomimo nieautentyczności architektury tego pałacu w kontekście lokalnej zabudowy Brighton, trudno nie docenić wspaniałego rzemiosła i artyzmu Johna Nasha, architekta odpowiedzialnego za ostatnią jego przebudowę. Dzięki temuż kunsztowi, a może po trosze także dzięki historii kolonialnej polityki Anglii, rezydencji tej nie określa się mianem kiczu, a jedynie dziwactwa czy kuriozum.

Przykład ten dowodzi, że sama tylko nieautentyczność stylu nie wystarcza, by dane dzieło architektoniczne określić jako kicz. Musi mu towarzyszyć cecha, która wyklucza jakiekolwiek realne użytkowanie wyrosłej z iluzji formy. W przypadku zapożyczeń lub ornamentu takie wykluczenie wynika przede wszystkim z nierealizowania dwóch funkcji architektury: zarówno tej związanej z potrzebą piękna (estetycznej), jak i z potrzebą dogłębnego, wielozmysłowego doświadczenia architektury (dzieło architektoniczne powinno wytwarzać odpowiednią „atmosferę”). Obydwie te funkcje nie zostają zrealizowane przy miernej, tandetnej jakości wykonania ornamentu i lichocie materiału. Dopiero w ten sposób iluzja staje się kiczem: namiastka wymarzonej rzeczywistości okazuje się jedynie namiastką jej wizerunku, działającą jak informacja o braku tego, co przywołuje w swoim pustym znaku. Świadome otaczanie się takimi atrapami wskazuje na chorobliwe upodobanie człowieka do własnego rozrzewnienia i bezwładu, które odrywają go od możliwości oferowanych przez rzeczywistość. W skali architektury taka atrapa powinna zostać wyeliminowana przez praktykę życiową. Jeśli natomiast utrzymuje się ona w mocy, może być rozpatrywana jako rodzaj patologii architektonicznej deformującej krajobraz oraz życie jej użytkowników.

Zgoła inne odczucia budzi w człowieku „namiastka szczęścia”, czyli forma powstała z iluzji (marzenia, życzenia), ale wykonana pięknie (kunsztownie, artystycznie). Niezależnie od tego, jak bardzo byłaby ona „nieautentyczna”, jeśli jest piękna, to oddziałuje na człowieka pięknem własnym, nie zaś cudzym, odbitym. Staje się wówczas „namiastką szczęścia”, która, choć zrodzona z iluzji, przestaje nią być dzięki rzeczywistemu pięknu. Nie jest zatem też kiczem. 
Myśl ta nawiązuje do koncepcji kiczu obecnej u Hermanna Brocha, a rozwijanej w latach 50. XX wieku. Według Brocha w prawdziwej sztuce piękno powstaje jako wyraz prawdy i dobra, jako efekt wytężonej pracy, a w przypadku kiczu celem nie jest piękno, lecz efekt piękna, który Broch nazywa dekoracją, ornamentem. Piękno (w sensie platońskim) stanowi ideał - to z definicji nieosiągalny wzór, istniejący poza systemem sztuki, która może do niego jedynie dążyć. „Otwartość” systemu, czyli niekończąca się droga do piękna, rozumiana jako proces odbierania sztuki przez człowieka (czyli jej doświadczania), jest gwarantem niewyczerpalnego potencjału sztuki i tkwiącej w niej mocy przyciągania (wielokrotnego, gdyż nie działa ona jak krótkotrwała informacja, lecz jest źródłem harmonii). Kicz natomiast zamienia abstrakcyjny ideał piękna w ograniczony i łatwo przyswajalny jego wizerunek. Stąd wniosek, że sztuka nie jest w stanie wyczerpać piękna jako swego źródła, kicz natomiast wyczerpuje je niezwykle szybko, co można łatwo rozpoznać w skali architektury.

\section{ORNAMENT W ARCHITEKTURZE}

Rozumienie kiczu, które proponuje Broch, współbrzmi z modernistycznym myśleniem o architekturze, w ramach którego ornament i dekoracja traktowane są jako nieprawdziwa (niestrukturalna, niekonstrukcyjna) część budowli, czyli swego rodzaju atrapa - bez względu na jakość jej wykonania. Trudno dziś jednak zachować aż tak bezwzględny osąd.

Nawet późniejsze, postmodernistyczne ujęcie ornamentu jako intencjonalnie żartobliwego cytatu $\mathrm{z}$ innej formy historycznej stanowi dziś raczej zamknięty etap historii myśli architektonicznej. Sam postmodernizm nie tyle zmienił definicję ornamentu, co usankcjonował jego obecność w architekturze i podniósł go do rangi wyróżnika stylowego oraz nośnika pożądanej narracji. Ornament postmodernistyczny nie wprowadza jednak do architektury żadnej iluzji, gdyż nie udaje, a przedrzeźnia obcą, najczęściej historyczną formę, dlatego należałoby go ujmować raczej jako „iluzję iluzji”, co oddala podejrzenia o kicz, który charakteryzuje się łatwością odbioru przez przeciętnego, masowego użytkownika architektury, a tym samym nie może opierać na wyrafinowanej intelektualnej grze.

Po doświadczeniach modernizmu i postmodernizmu, których pewne przejawy są wciąż obecne w architekturze, współczesna krytyka architektoniczna oddala się od utożsamiania kiczu architektonicznego z ornamentyką. 
Aktualne nurty refleksji, opowiadające się za autentycznością i uznające iluzję za źródło kiczu, proponują głębszą analizę ornamentu i dekoracji pod kątem tkwiącego $\mathrm{w}$ nich potencjału wzbogacenia wielozmysłowego doświadczenia architektury. Jest to przede wszystkim konsekwencją położenia nacisku na atmosferę architektury jako jedną z jej podstawowych funkcji. Zmienia to stosunek do ornamentu, którego „użytkowość” polega najczęściej właśnie na tworzeniu konkretnej atmosfery. Sam ornament nie jest już zatem wartościowany negatywnie, jak w modernizmie (jako nieprzynależny do konstrukcyjnej i strukturalnej warstwy architektury), ale w oparciu o kategorię atmosfery, w której mieści się zarówno wartość piękna, jak i wielozmysłowe doświadczanie architektury przez człowieka.

Fakt, że o kiczu nie myśli się już w kontekście ornamentyki, zilustrować może szczególny dziś przypadek kiczu architektonicznego związany z tak zwaną „architekturą minimalistyczną”. Współcześnie w budownictwie jednorodzinnym nośnikiem marzenia i życzenia rzadko są zapożyczenia $\mathrm{z}$ form odległych w czasie i przestrzeni, częściej natomiast - styl architektoniczny wybrany $\mathrm{z}$ wielu aktualnie istniejących w Polsce. Formy minimalistyczne szybko uznane zostały za wyznaczniki prestiżu, zamożności i luksusu oraz przynależności do nieformalnej społecznie, elitarnej grupy intelektualistów (podczas gdy wczesny minimalizm miał raczej redukować przesyt do umiaru, powściągliwości i bezpretensjonalnej czystości form). Wprawdzie także w tym przypadku to kunszt wykonania decyduje, czy dany obiekt można uznać za przykład kiczu, jednak przykład ten świadczy o tym, że iluzja i nieautentyczność mogą manifestować się także w odrzuceniu wszelkiego ornamentu i dekoracji.

\section{PODSUMOWANIE}

Architektura jest dobrym obszarem ustalania/testowania kryteriów rozpoznawania kiczu oraz odróżnienia go od nie-kiczu. Jest to możliwe dzięki jej skali - zarówno czasowego trwania, jak i fizycznych rozmiarów - a także konieczności spełniania potrzeb życiowych użytkownika. Iluzja w architekturze jest kiczem, jeśli w zrealizowanej formie wciąż pozostaje iluzją atrapą rzeczywistości wykluczoną $\mathrm{z}$ funkcji zaspokajania owych potrzeb. Taka iluzja-kicz pogłębia w człowieku uczucie braku oraz smutek wynikający z niemożności spełniania marzenia. Kicz zatem odrywa człowieka od rzeczywistości. 
Natomiast iluzja, która jest przyczyną powstania konkretnego dzieła architektury, może zniknąć w zrealizowanej formie, jeśli jest ona architektonicznie funkcjonalna i użyteczna. Szczególną potrzebą człowieka, którą spełniać może i powinna architektura, jest potrzeba piękna oraz dogłębnego (cielesnego i umysłowego) doświadczenia rzeczywistości. Dlatego iluzja, „ucieleśniona” w pięknej formie architektonicznej, właśnie dzięki swemu pięknu przestaje być iluzją i źródłem kiczu - przekształca się w „namiastkę szczęścia”, która potrafi wzbogacić doświadczenie rzeczywistości, a nie odciągnąć od niej, jak to się dzieje w przypadku kiczu.

\section{Bibliografia}

Theodor W. Adorno, Sztuka i sztuki: wybór esejów, tłum. K. Krzemień-Ołak, PIW, 1990.

Herman Broch, Kilka uwag o kiczu i inne eseje, Czytelnik, Warszawa 1998.

Kinga Baumann,, O kiczu, campie $i$ architekturze ujarzmionej pragmatyzmem, „Architektura \& Biznes” 2005, nr 5(154).

Encyklopedia psychologii, red. Wł. Szewczuk, Fundacja Innowacja, Warszawa 1998. Barbara Stec, Kiedy forma staje się postawa, czyli o autentyczności w architekturze, "Architektura \& Biznes” 2013, nr 11(256).

Barbara Stec, Maniera tenebrosa, czyli o autentyczności $w$ architekturze c.d., „Architektura \& Biznes” 2014, nr 6(263).

Barbara Stec, Odpowiednie dać rzeczy słowo, czyli o autentyczności w architekturze cd., „Architektura \& Biznes” 2014, nr 4(261).

Barbara Stec, Piękno skupienia, czyli o autentyczności cd. - miejsca skupienia i rozproszenia, „Architektura \& Biznes” 2014, nr 1(258).

Barbara Stec, Powtórne spojrzenie, cz. 1, „Architektura \& Biznes” 2005, nr 5(154).

\section{Reflection on Kitsch in Architecture. Illusion or a Bit of Happiness?}

The reflection in this article is focused on the kitsch in architecture. The term 'kitsch' itself, originally referred to the images, is nowadays also used for the evaluation of architecture, especially in terms of its authenticity. This requires taking into account the physical scale associated with the function important in architecture, that is, the one of satisfying the needs of its user. What served as a starting point for reflection was the thought of Kurt W. Forster, in which he identified kitsch, including the architectural 
one, with the illusion of a better life, inherent in the dream and desire of a man, and constituting the cause of architectural borrowings.

It was noted that in architecture, because of its scale and utility, the illusion cannot replace the real fulfillment of the user's life needs, so it may exist for a relatively short period of time so as to lead to the emergence of its form, or, in the long run, it may subsist next to reality as a useless dummy, excluded from the function of satisfying the needs of the user. Such a kitsch can be seen in architecture, in which a man lives for such a short time that he or she does not need to meet one's needs based on kitsch.

The prolonged use of architectural kitsch deepens in a man a feeling of sadness and irritation resulting from a sense of inability to fulfill dreams or real needs. And if the illusion is only a cause of the architecture - since it disappears into its realized form, borrowed, but useful (as theatre decoration, by meeting the needs of beauty or a multi-sensory experience of architecture) - then you cannot talk about the architectural kitsch, understood as an illusion. Accordingly, the ornament also need not be kitsch if it converts the illusion into a bit of happiness.

Keywords: reality, illusion, beauty, kitsch, architecture, architectural scale, building, dummy, ornament 